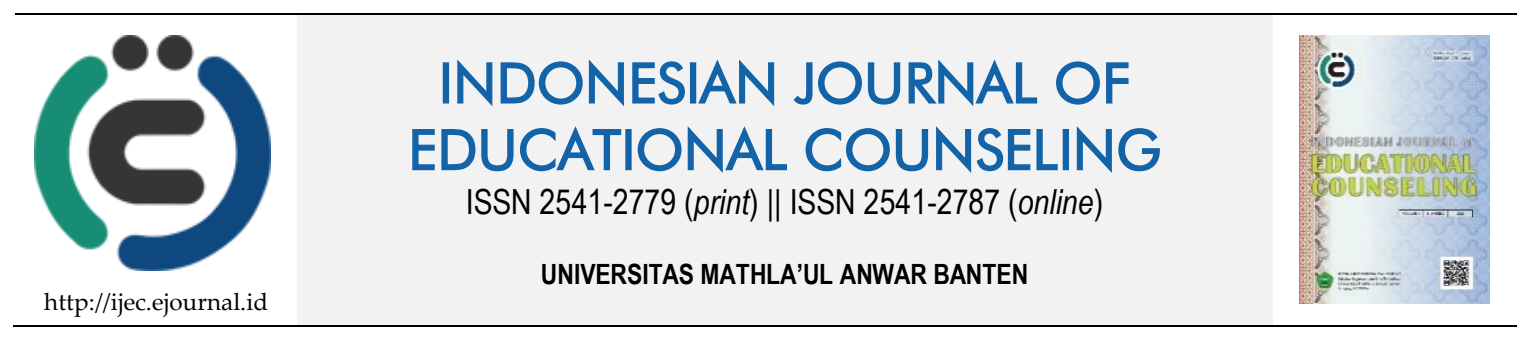

Research Based Article

\title{
Resilience and Gender as Determinants of Entrepreneurial Intentions among Secondary School Students in Kwara State, Nigeria
}

\begin{tabular}{|c|c|}
\hline \multicolumn{2}{|c|}{ Umar Talatu Ibrahim ${ }^{1}$} \\
\hline & ${ }^{1}$ Umar Musa Yar'adua University, Nigeria \\
\hline Article History & ABSTRACT \\
\hline $\begin{array}{l}\text { Received: } 16.03 .2020 \\
\text { Received in revised form: } \\
17.06 .2020 \\
\text { Accepted: } 25.06 .2020 \\
\text { Available online: } 28.07 .2020\end{array}$ & $\begin{array}{l}\text { The purpose of this study was to investigate resilience and gender as } \\
\text { determinants of entrepreneurial intentions among secondary school students in } \\
\text { Kwara State, Nigeria. Descriptive research design of ex-post-facto type was } \\
\text { used in the study. Five hundred respondents were selected randomly from } 5 \\
\text { Local Government Area in Kwara State, Nigeria. The respondents were } \\
\text { measured with validated scale and the data obtained was analyzed using the } \\
\text { Pearson Product Moment Correlation (PPMC) statistical analysis. Two research } \\
\text { hypotheses were formulated and tested at } 0.05 \text { level of significance. The result } \\
\text { showed that there was significant relationship between the resilience and } \\
\text { entrepreneurial intentions among secondary school students ( } \mathrm{r}=0.817 \text {; } \mathrm{p}<0.05) \\
\text { and there no significant difference in the entrepreneurial intentions of male and } \\
\text { female secondary school students ( } \mathrm{t}=0.71 ; \mathrm{p}>0.05 \text { ). In view of these findings, } \\
\text { the study recommended that the entrepreneurship training should be made } \\
\text { compulsory at all levels of learning from primary schools to the tertiary } \\
\text { institutions and curriculum should be tailored towards learning the skills for } \\
\text { starting businesses after graduation from school, thus changing the orientation } \\
\text { of the students at an early stage towards entrepreneurship. }\end{array}$ \\
\hline & KEYWORDS: Entrepreneurial Intentions, Gender, Resilience, Secondary School \\
\hline
\end{tabular}

DOI: $10.30653 / 001.202042 .132$

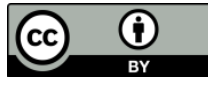

This is an open access article distributed under the terms of the Creative Common Attribution 4.0 International License, which permits unrestricted use, distribution, and reproduction in any medium, provided the original work is properly cited. (๑) 2020 Umar Talatu Ibrahim.

\section{INTRODUCTION}

Entrepreneurship is a key driver of the economy in developed countries. The alarming rate of unemployment among Nigerian university graduate students has grave consequences for the growth and development of the nation. Wealth and majority of jobs are created by small businesses started by entrepreneurial minded individuals, many of whom go on to create big businesses. These individuals who are exposed to entrepreneurship frequently are likely to have more opportunity to exercise creative freedom, higher self-esteem, and an overall greater sense of control over their own lives.

1 Corresponding author's address: Department of Education, Umar Musa Yar'adua University, Katsina State, Nigeria. Email: muraina_kamilu@yahoo.com 
This is not the situation in Nigeria because the integration of entrepreneurship into the education system is a relatively new concept in Nigeria. In Nigeria, graduates find it difficult to secure jobs after their graduation and this has been traced to the nonavailability of courses in their institutions that will assist or train them towards thinking about creating jobs for themselves and creating wealth for the economy.

There is a lack of congruence between the skills/programmes of university graduates from our tertiary institutions and labour market job required skills. After the compulsory National Youth Service Corps (NYSC), most graduates are without jobs and remain jobless for months and even years. This is perhaps because most students believe they are in school to learn how to secure good white collar jobs after graduation and have a difficulty of removing the mentality of white collar jobs as the main and best option for tertiary institution graduates. Entrepreneurship as a concept is known and appreciated all over the world, especially in developed countries. Increasingly, it is becoming an important issue for policy makers trying to search for new ways of increasing and improving economic growth, through job creation and innovation. This is because the 21st century labour market is laden with challenges where a number of professionals are confronted with the choice of creating their own company. A development that occurred because of limited job opportunities and /or the fear of losing their present employment (Bird, 1988; Krueger, Reilly, \& Carsrud, 2000). Entrepreneurial intention is the cognitive representation of the actions to be implemented by individuals to either establish new independent ventures or to create new value within existing companies (Fini, Grimaldi, Marzocchi \& Sobrero, 2009).

Intentions have been proved to be the best predictor of individual behaviour particularly when the behaviour is rare, hard to observe or involves unpredictable time lags (Krueger \& Brazeal, 1994). The establishment of new ventures and the creation of new value in existing ones, which have been identified by Bird (1988) as the two outcomes of entrepreneurial intentions, are good examples of such behaviour. The decision to become an entrepreneur may be plausibly considered as voluntary and conscious (Ajzen, 2001), thus, it seems reasonable to analyse how that decision is taken. Entrepreneurship may be viewed as a process that occurs over time (Adeleke, 2007). Therefore, according to Lee and Wong (2004), entrepreneurial intentions would be the first step in the evolving and sometimes long-term process of venture creation. Again, the intention to start-up, would be a previous and determinant element towards performing entrepreneurial behaviour (Fayolle \& Gailly, 2004) and the single best predictor of that behaviour (Ajzen, 2001).

A number of factors from literature, especially in developed countries have been adduced to be responsible for the reason why some people choose to be self-employed and start their own businesses and others are oriented to seeking the traditional salary employment. Factors in the present study which could be a useful measure on the entrepreneurial intention of participants are resilience and gender which are relatively new to research on entrepreneurial intention.

Resilience is the important factor regarding creating new ventures. It involves risk bearing ability of an individual. Creating a new firm could be a risky undertaking. This could be as a result of individual or personal as well as environmental factors which could pose as threats to the start or establishment of new ventures. Krueger and Dickson (1994) reported that resilience is enhanced by perceptions of opportunity and undermined by perceptions of threat and therefore, risk propensity can be defined as a tendency to take or avoid risks. It is a relatively stable characteristic which can be modified through 
experience. Although it is viewed as an individual characteristic, the positive association between resilience and entrepreneurial intention by individuals is expected to translate to organizations through top management teams (Panzano \& Billings, 2005). Resilience depends on risk propensity and perception. The higher the resilience and the lower the risk perception, the more likely it is that risky decisions will be made. Liles (1974) argue that entrepreneurs must accept uncertainty with respect to financial well-being, psychic well-being, career security and family relations. Considerable researches have been undertaken in pursuit of the notion that a fundamental characteristic of the entrepreneur is his or her resilience (Brockhaus, 1982).

Eccles (1994) showed that psychological characteristics such as resilience and entrepreneurial self-efficacy, in addition to developed skills and abilities, influence entrepreneurial intentions. Krueger and Dickson (1994) disagreed with this when they advocated that entrepreneurs take calculated risks. Hull, Bosley and Udell (1980) observe potential entrepreneurs to have a greater resilience. Their definition of an entrepreneur includes anyone who owned a business, assumed risk for the sake of profit and had the explicit intention of expanding the business. Findings on the resilience of entrepreneurs have basically been unconfirmed, inconclusive and inconsistent. For example, Begley and Boyd (1987) conducted a study in England with a sample of 239 members of a small business association to determine the difference in psychological characteristics of entrepreneurs and small business managers. Using a survey questionnaire to elicit respondent's perceptions, the researchers found significant differences between entrepreneur's resilience as compared to small business managers.

Gender can exert a powerful influence on cognition and behaviour (Heilman, 2001). These stereotypes reflect as well as influence the clear divide between men and women in many achievement-related domains for example, business creation (Nosek, Banaji, \& Greenwald, 2002). It has been increasingly recognised that female entrepreneurs are an important and growing proportions of the economy, with higher than average success rates (Carter, 2000). Gender-based research on entrepreneurs has generally indicated that similarities between the two sexes outweigh the differences (Brush, 1992). In the efforts to debunk a number of the disparaging myths concerning women entrepreneurs, Brush, Carter, Gatewood, Greene and Hart (2004); Menzies, Diochon, and Gasse (2004) point to some underlying patterns that may help explain growth limitations in women-owned ventures. Their findings suggest that women were less likely to have educational backgrounds in engineering and computing and tended not to take classes on how to start a business.

Males express higher levels of entrepreneurial intentions than females. To capture the talents of women in future new venture creation, a vibrant pipeline of potential entrepreneurs is required. However, previous research has shown that this pipeline may be weak. Although many potential factors may contribute including access to capital, previous research has shown that entrepreneurial self-efficacy that is; the self-confidence that one has the necessary skills to succeed in creating a business plays an important positive role in determining level of interest in pursuing an entrepreneurial career among young people (Kickul, Wilson, \& Marlino, 2004). Previous research suggests adult women are more likely to shun entrepreneurial endeavours and to limit their ultimate career choices because of a lack of confidence in relevant skills (Bandura, 1992).

In examining gender differences, empirical evidence suggests that women are likely to have lower expectations for success in a wide range of occupations (Eccles, 1994) than 
men, particularly in careers that have been seen in the past as non-traditional for women (Bandura, Barbaranelli, Caprara \& Pastorelli, 2001). In order to fill the gaps in the previous study and add more to the existing literatures, the present study intends to resilience and gender as determinants of entrepreneurial intentions among secondary school students in Kwara State, Nigeria.

\section{METHOD}

The research design for this study was a descriptive survey research design of $e x-$ post-facto type. This approach does not involve the manipulation of variables in the study. It is therefore, after the fact study. It neither add to nor deduct from the existing fact. The population for this study covered all secondary schools in 16 Local Government Area of Kwara State, Nigeria. Simple random sampling technique was used in this study. Five (5) Local Government Areas were randomly selected in Kwara State. In each randomly selected LGA, 10 public secondary schools were randomly selected. Also, in each randomly selected secondary school, 10 secondary school students were selected through balloting. On the whole, total numbers of participants selected were 500 students.

\section{Entrepreneurial Intentions Scale (EIS)}

Entrepreneurial intentions scale developed by Krueger, Reilly, and Carsrud (2000) was used to measure the students' entrepreneurial intentions. The scale contained 10 items based on 5-points which are Strongly Disagree, Disagree, Undecided, Agree and Strongly Agree. The scale according to the Author had internal consistency of 0.70 and reliability indices of 0.81 . The instrument was however re-validated and Cronbach alpha value of .85 was obtained after administering the instruments in a pilot study to a selected sample of twenty (20) secondary school students who are not part of the samples for this study.

\section{Resilience Scale (RS)}

Resilience scale developed by Brockhaus (1982) was used to measure the resilience of the respondents. The scale has 10 items based on 5-points which are Strongly Disagree, Disagree, Undecided, Agree and Strongly Agree. The scale according to the Author had internal consistency of 0.79 and reliability indices of 0.84 . The instrument was however revalidated and Cronbach alpha value of .86 was obtained after administering the instruments in a pilot study to a selected sample of twenty (20) secondary school teachers who are not part of the samples for this study.

The instrument was administered to the respondents on the day approved by the school authorities for the exercise. The researcher was assisted by trained research assistants in the administration and collection of the questionnaire. In each of the selected school, the administration and collection of instruments were done on the same day. On the whole, data collection lasted for 5 weeks. Out of 500 questionnaires administered only 472 were retrieved and used for data analysis. The data collected from the study was analyzed, using Pearson Product Moment Correlation (PPMC) statistical method at 0.05 level of significance. 


\section{RESULT AND DISCUSSION}

Significant relationship between the resilience and entrepreneurial intentions among secondary school students $(\mathrm{r}=.817 ; \mathrm{p}<0.05)$. This means that resilience has significant influence on entrepreneurial intentions among secondary school students.

Table 1. Significant relationship between the resilience and entrepreneurial intentions among secondary school students

\begin{tabular}{llllllll}
\hline Variables & Mean & SD & DF & N & r & p & Remark \\
\hline Resilience & 31.51 & 24.32 & & & & & \\
Entrepreneurial & 27.83 & 11.27 & 472 & 470 & $.817^{* *}$ & .000 & Significant \\
Intentions & & & & & & & \\
\hline
\end{tabular}

* Significant at $\mathrm{p}<0.05$

Significant difference in the entrepreneurial intentions of male and female secondary school students $(t=.71 ; p>0.05)$. The mean value of the table further revealed that female students had slightly higher entrepreneurial intentions distress than their male counterpart but the difference was not statistical significant. This further meant that gender had no significant influence on entrepreneurial intentions of students.

Table 2. Significant difference in the entrepreneurial intentions of male and female secondary school students

\begin{tabular}{lllllllll}
\hline Gender & $\mathrm{N}$ & Mean & $\mathrm{SD}$ & Std. Error & $\mathrm{DF}$ & $\mathrm{t}$ & $\mathrm{p}$ & Remark \\
\hline Male & 218 & 34.34 & 7.82 & 1.51 & & & & \\
Female & 254 & 36.11 & 9.95 & .76 & 470 & .71 & 0.63 & $* \mathrm{~S}$ \\
\hline
\end{tabular}

* Significant at $\mathrm{p}<0.05$

The result of the first research hypothesis showed that there was significant relationship between the resilience and entrepreneurial intentions among secondary school students. This means that resilience has significant influence on entrepreneurial intentions among secondary school students. This is in line with the finding of Krueger and Dickson (1994) who found that resilience is enhanced by perceptions of opportunity and undermined by perceptions of threat and therefore, risk propensity can be defined as a tendency to take or avoid risks. It is a relatively stable characteristic which can be modified through experience. Although it is viewed as an individual characteristic, the positive association between resilience and entrepreneurial intention by individuals is expected to translate to organizations through top management teams (Panzano \& Billings, 2005). Liles (1974) argue that entrepreneurs must accept uncertainty with respect to financial well-being, psychic well-being, career security and family relations. Considerable researches have been undertaken in pursuit of the notion that a fundamental characteristic of the entrepreneur is his or her resilience (Brockhaus, 1982). Eccles (1994) showed that psychological characteristics such as resilience and entrepreneurial selfefficacy, in addition to developed skills and abilities, influence entrepreneurial intentions. Krueger and Dickson (1994) disagreed with this when they advocated that entrepreneurs take calculated risks. Hull, Bosley and Udell (1980) observe potential entrepreneurs to have a greater resilience. Their definition of an entrepreneur includes anyone who owned a business, assumed risk for the sake of profit and had the explicit intention of expanding 
the business. Findings on the resilience of entrepreneurs have basically been unconfirmed, inconclusive and inconsistent.

The result of the second research hypothesis showed that there no significant difference in the entrepreneurial intentions of male and female secondary school students. The mean value of the table further revealed that female students had slightly higher entrepreneurial intentions distress than their male counterpart but the difference was not statistical significant. This further meant that gender had no significant influence on entrepreneurial intentions of students. This is in line with the finding of Carter (2000) who found that female entrepreneurs are important and growing proportions of the economy, with higher than average success rates). Gender-based research on entrepreneurs has generally indicated that similarities between the two sexes outweigh the differences (Brush, 1992). In the efforts to debunk a number of the disparaging myths concerning women entrepreneurs, Brush, Carter, Gatewood, Greene and Hart (2004); Menzies, Diochon, and Gasse (2004) point to some underlying patterns that may help explain growth limitations in women-owned ventures. Their findings suggest that women were less likely to have educational backgrounds in engineering and computing and tended not to take classes on how to start a business. Males express higher levels of entrepreneurial intentions than females. However, previous research has shown that this pipeline may be weak. Although many potential factors may contribute including access to capital, previous research has shown that entrepreneurial self-efficacy that is; the self-confidence that one has the necessary skills to succeed in creating a business plays an important positive role in determining level of interest in pursuing an entrepreneurial career among young people (Kickul, Wilson, \& Marlino, 2004). Previous research suggests adult women are more likely to shun entrepreneurial endeavours and to limit their ultimate career choices because of a lack of confidence in relevant skills (Bandura, 1992).

\section{CONCLUSION}

This research work has been able to examine resilience and gender as determinants of entrepreneurial intentions among secondary school students in Kwara State, Nigeria. It is therefore concluded that both the parents, teachers, students and even the government should as a matter of urgency should rise to put entrepreneurial programmes in place to get students more involved in community life and be more relevant to the development of society at large. The study had identified several implications of the findings to both counselling and educational setting considering the fact that resilience predicts entrepreneurial intention among students. Psychologists working in higher institutions of learning should consider assisting these undergraduates to develop those factors that have been identified as potent in fostering entrepreneurial intention. Entrepreneurship education is a means through which government could attain such development in the society. Entrepreneurship education as part of the total educational system is the type of education that involves the acquisition of skills, ideas and management abilities necessary for job creation. An entrepreneur promotes employment rather than seeking for an employment. Therefore, there is a need to embrace this type of education and provide all the necessary resources needed to make functional. Quality entrepreneurship education could be used as a tool for fighting the war against poverty and unemployment in Nigeria. 


\section{REFERENCES}

Adeleke, J. O. (2007). Identification and effect of cognitive entry characteristics on students' learning outcomes in bearing in Mathematics, Unpublished Ph. D Thesis, University of Ibadan.

Ajzen, I. (2001). Nature and operation of attitudes. Annual Review of Psychology, 52(1), 2758.

Bandura, A. (1992). Exercise of personal agency through the self-efficacy mechanisms. Selfefficacy: Thought control of action (Ed. R. Schwarzer). Washington, DC: Hemisphere.

Bandura, A., Barbaranelli, C., Caprara, G. V., \& Pastorelli, C. (2001). Self-efficacy beliefs as shapers of children's aspirations and career trajectories. Child Development, 72(1), 187 206.

Begley, T. M., \& Boyd, D. P. (1987). A comparison of entrepreneurs and managers of small business firms. Journal of Management, 13(1), 99-108.

Begley, T. M. and Boyd, D. P. (1986). Psychological characteristics associated with Entrepreneurial Performance. In R. Ronstadt (Ed.), Frontiers of Entrepreneurship Research (pp. 146-165). Wellesley, Mass: Babson Center for Entrepreneurial Studies.

Bird, B. (1988). Implementing entrepreneurial ideas: The case for intention. Academy of Management Review, 13(3), 442-453.

Brockhaus, R. (1982). The Psychology of the entrepreneur. In C. Kent, D. Sexton, \& K. H. Vesper (Eds.), Encyclopaedia of Entrepreneurship. Englewood Cliffs, NJ: Prentice-Hall.

Brush, C., Carter, N., Gatewood, E., Greene, P. and Hart, M. (2004). Clearing the Hurdles: women building high-growth Businesses. Saddle River, NJ: Financial Times Prentice Hall Books.

Brush, C. G. (1992). Research on women business owners: Past trends, a new perspective and future directions. Entrepreneurship Theory and Practice, 16(4), 5-30.

Carter, S. (2000). Improving the numbers and performance of women-owned businesses: some implications for training and advisory services. Education+ Training, 42, 326333.

Eccles, J. S. (1994). Understanding women's educational and occupational choices: Applying the Eccles et al. model of achievement-related choices. Psychology of Women Quarterly, 18(4), 585-609.

Fayolle, A., \& Gailly, B. (2004). Using the theory of planned behaviour to assess entrepreneurship teaching programs: a first experimentation. In IntEnt2004 Conference (pp. 5-7). International Enterprise 2004 Conference, Naples (Italy), 5-7 July 2004. 
Fini, R., Grimaldi, R., Marzocchi, G. L., \& Sobrero, M. (2009). The foundation of entrepreneurial intention. Research seminars, Center for Strategic Management and Globalization at Copenhagen Business School, Copenhagen, Denmark. Retrieved February, 22, 2009 from http://ssrn.com/abstract=1313225

Heilman, M. E. (2001). Description and prescription: How gender stereotypes prevent women's ascent up the organizational ladder. Journal of Social Issues, 57(4), 657-674.

Hisrich R. D., \& Peters, M. P. (1998). Entrepreneurship, 4th ed n. New York: Prentice Hall.

Hull, D. L., Bosley, J. J., \& Udell, G. G. (1980). Renewing the hunt for the heffalump, 1dentifying potential entrepreneurs by personality characteristics. Journal of Small Business, 18(1), 11-18.

Kickul, J., Wilson, F., \& Marlino, D. (2004). Are misalignments of perceptions and self efficacy causing gender gaps in entrepreneurial intentions among our nations' teens?. Manuscript Presented at Babson-Kauffman Research Conference, Glasgow, Scotland.

Krueger Jr, N. F., \& Brazeal, D. V. (1994). Entrepreneurial potential and potential entrepreneurs. Entrepreneurship theory and practice, 18(3), 91-104.

Krueger Jr, N. F., Reilly, M. D., \& Carsrud, A. L. (2000). Competing models of entrepreneurial intentions. Journal of business venturing, 15(5-6), 411-432.

Lee, S. H., \& Wong, P. K. (2004). An exploratory study of technopreneurial intentions: A career anchor perspective. Journal of Business Venturing, 19(1), 7-28.

Liles, P. R. (1974). New business ventures and the entrepreneur. Homewood, Illinois: Irwin.

Menzies, T. V., Diochon, M., \& Gasse, Y. (2004). Examining venture-related myths concerning women entrepreneurs. Journal of Developmental Entrepreneurship, 9(2), 89107.

Nosek, B. A., Banaji, M. R., \& Greenwald, A. G. (2002). Mathematics for male and female. Journal of Personality and Social Psychology, 83(1), 44-59

Panzano, P. C., \& Billings, R. S. (2005). An organisational level test of a partially mediated model of risky decision-making behaviour. Retrieved December, 1, 2009. from http://www.dssincorporated.com/Research/RiskyDecision/risky.html. 